\title{
外科手術書の「結び」の呼称
}

小池壽 男

The Diction in Regard to "Knot" in the Textbook of Surgical Operations

\section{Toshio KOIKE}

外科手術の基本的な手技の一つに結禁があり， 獣医外科臨床では日常的に用いられている。した がって外科手術書の基礎的記述の中に図解説明さ れている。近年, 我国の外科手術書における系結 びの説明に用いられている「結び」の呼称に混乱 があり，特に邦文名でそれが著しく，従来の日本 の慣習との関連でも不都合な表現と思われる点も ある。

\section{1. 外科手術書での呼称}

外科手術書で「結び」を図解説明しているもの からの邦文呼称を著書の発行年順にまとめてみる と, 表 1 のよになる。Aの結び方は外科結節あ るいは外科結びと称してほぼ一貫しているが， B およびCの結び方の呼称においては 1960 年代後 半から混乱がみられる。これに対して欧文名は, 表 2 のようにほぼ一定である。

2. 慣習としての呼称

大辞典 $(1935)^{16)}$ によれば「結び」について次 のようにのべている。

○オトコムスビ 男結。諸結の一。垣・矢来等の 緒の結び方。女結に対す。右の端を左の下にまわ し更に右に返して輪を作り，左の端をまわしてそ の輪に通して結ぶもの。

○オンナムスビ 女結。緒の結び方。男結が右か ら始めるのを左から始めるもの。

酪農学園大学（北海道江別市, 干069)

Rakuno Gakuen University, Ebetsu, Hokkaido 069, Japan
○コマムスビ 小間結, 細結。紐の結び方の一。 左右の先端を二度からませて結び, あとえ戻すこ

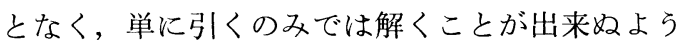
に結ぶこと。本結，真結。

○タテムスビ 縦結。結び方の一。こまむすび, てふむすび等の斜めに㨝れ歪みたるもの。

また大辞林 $(1988)^{11)}$ によれば次の様に述べて いる。

○おとこむすび 男結び。ひもの結び方の一。右 端を左端の下にまわして返した輪に左端を通して 結ぶ。解けにくいので垣根・矢来・門松などを結 ぶときに用いる。

○扒んなをすび 女結び。ひもの結び方の一。男 結びの結び方を左から始めたもの。

○こまむすび 細結び，小間結び。紐の両端を交 差させて結び，再び交差させて結ぶ結び方。真結 び，玉結び。

○たてむすび 縦結び，結んだ紐の先が組と平行 にならず, 十の字になる結び方。

これ等の結び方は，打汪つき四郎編著の「なわ 結び」(1975) ${ }^{13)}$ に詳細に図解されて沶り, 男結び と女結びは図 1 のようになる。

\section{3. 考察}

紐の結び方は大別すると作業的結び方，装飾的 結び方および記録的結び方の 3 種 ${ }^{17)}$ となり外科手 術でのものは，作業的なものの中での繫ぎ合せ （結合）の結び方に属している。

今回の外科手術時の「結び」の邦文名に於ける 
表 1 結びの邦文名

\begin{tabular}{|c|c|c|c|c|}
\hline \multirow[b]{3}{*}{ 年代 } & 結 & び & \multirow[b]{2}{*}{$\mathrm{C}$} & \multirow[b]{3}{*}{ 文南 } \\
\hline & A & $\mathrm{B}$ & & \\
\hline & & & & \\
\hline 1935 & 外科的結節 & $\begin{array}{l}\text { 立結 } \\
\text { 婦女結節 }\end{array}$ & 尋常結節 & 22 \\
\hline 1946 & 外科結び & 男結び & 女結び & 9 \\
\hline 1955 & 外科結び & 男結び & 女結び & 10 \\
\hline 1955 & 外科結節 & $\begin{array}{l}\text { 婦女結節 } \\
\text { 立結 }\end{array}$ & 尋常結節 & 6 \\
\hline 1963 & 外科結節 & 婦女結節 & 尋常結節 & 7 \\
\hline 1965 & 外科結び & 女結び & 男結び & 5 \\
\hline 1967 & 外科結び & $\begin{array}{l}\text { 女結び } \\
\text { たて結び }\end{array}$ & 男結び & 4 \\
\hline 1970 & 外科結び & $\begin{array}{l}\text { 逆結び } \\
\text { 男結び }\end{array}$ & $\begin{array}{l}\text { 角結び } \\
\text { 女結び }\end{array}$ & 20 \\
\hline 1981 & 外科結び & 男結び & 女結び & 8 \\
\hline 1985 & 外科結ば & $\begin{array}{l}\text { 逆結び } \\
\text { 女結び }\end{array}$ & $\begin{array}{l}\text { 角結び } \\
\text { 男結び }\end{array}$ & 21 \\
\hline 1986 & 外科結び & 立結び & こま結び & 19 \\
\hline 1987 & $\begin{array}{l}\text { 外科結び } \\
\text { 外科結節 }\end{array}$ & $\begin{array}{l}\text { 女結び } \\
\text { 婦女結節 } \\
\text { たて結び } \\
\text { 逆結び }\end{array}$ & $\begin{array}{l}\text { 男結び } \\
\text { 尋常結節 } \\
\text { 本結び } \\
\text { こま結び }\end{array}$ & 3 \\
\hline
\end{tabular}

混乱は, Bの結び方のドィッ語名のWeiberknoten を婦女結節と邦訳したことから，これを 女結びと称してこれに対するものとしてCの結び 方に男結びの語を当てたことにより，さらにBが 時には男結びと俗称されていることなどが加わっ て生じたものと思われる。

しかしながら，本来の日本語にある男結びおよ び女結びはここに挙げた BおよびCの結び方とは 異なる結び方を指していることが明らかである。 このよらな混乱の原因は学術用語としての「結

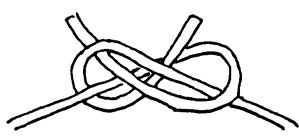

罗絬で

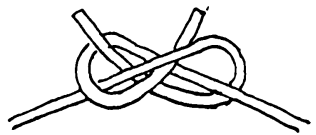

女絬び
図 1 男結び・女結び

び」に男結びあるいは女結びの用語を安易に用い た点にもある。すでに医学の外科領域にあって は男結び・女結びを用いずBに対しては立結び, 
表 2 結びの欧文名

\begin{tabular}{|c|c|c|c|c|}
\hline \multirow{2}{*}{ 年代 } & \multicolumn{3}{|c|}{ 形 } & \multirow{2}{*}{ 文献 } \\
\hline & A & B & $\mathrm{C}$ & \\
\hline 1935 & $\begin{array}{c}\text { chirurgischer } \\
\text { Knoten }\end{array}$ & Weiberknoten & Schifferknoten & 22 \\
\hline 1956 & $\begin{array}{c}\text { Chirurgischer } \\
\text { Knoten }\end{array}$ & & Schifferknoten & 1 \\
\hline 1961 & $\begin{array}{l}\text { Chirurgischer } \\
\text { Knoten }\end{array}$ & & Schifferknoten & 2 \\
\hline 1966 & Surgical knot & & Reef knot & 15 \\
\hline 1979 & & Granny knot & Square knot & 23 \\
\hline 1985 & Surgeon's knot & Granny knot & Square knot & 18 \\
\hline 1986 & surgeon's dnot & granny knot & square knot & 19 \\
\hline 1987 & Surgeon's knot & Granny knot & Square knot & 14 \\
\hline 1987 & $\begin{array}{l}\text { surgical knot } \\
\text { surgeon's knot }\end{array}$ & granny knot & $\begin{array}{l}\text { square knot } \\
\text { sailors knot } \\
\text { reef knot }\end{array}$ & 3 \\
\hline
\end{tabular}

Cにはこま結びなどの用語をそれぞれ用いる傾向 にある12,19)。獣医外科領域においてもこの様な日 常的に用いられる「結び」の用語に混乱があるこ とは好ましくなく，この様な混乱のある男結び・ 女結びの用法から脱却し，立結びあるいはこま結 びなどを用いる時期と言えよう。

\section{参 考 文 䒜}

1) Berge, E. (1956) : Tierarztlich Operationslehre, pp. 4-5, Paul Parey, Berlin.

2) Berge, E. u. Westhues, M. (1961): Tierarztlich Operationalehre, 28th ed., pp. 6-8, Paul Parey, Berlin.

3) 後藤 稠, 他編 (1987) : 最新医学大辞典, p. 397 , 医歯薬出版, 東京。

4) 市川篤二, 他 (1967) : 手術のコッ, pp. 89 , 金原出版, 東京。

5) 井上 雄 (1965)：新しい外科手術 (上巻), pp. 8-9, 南江堂, 東京。

6) 黒澤亮助 (1955) : 家畜外科手術学, pp. 3839, 養賢堂, 東京。
7) 黒澤亮助, 他 (1963)：家畜外科診療, 1 版, p. 96, 養賢堂, 東京。

8）黑澤亮助, 酒井 保 監修(1981)：家畜外 科診療, 増改 1 版, p. 138, 養賢堂, 東京。

9) 松葉重雄 (1946) : 獣医外科手術学, pp. 110-111，金原出版，東京。

10) 松葉重雄 (1955)：獣医外科手術学, 改訂 8 版, pp. 108-109, 金原出版, 東京。

11）松村 明 (1988)：大辞林, pp. 344，381, 912，1492, 三省堂, 東京。

12）日本整形外科学会学術用語委員会編 (1977)：整形外科学用語集, p. 65, 日本整 形外科学会, 東京。

13）おほつき四郎 編(1975) : なわ（ロープ， 紐, 系) 結び, pp. 30-31，66-67, 総合科 学出版, 東京。

14) Robin, E. and Robinson, G.M. (1989) : Knot security of suture materials. Vet. Surg., 18, 269-273.

15) Siller, W.G. and Fraser, J.A. (1966) : Veterinary Operative Surgery, pp. 8-9, 
Medical Book Co., Copenhagen.

16) 下中邦彦 (1935)：大辞典, 五巻, pp. 92, 306. 十一巻 p. 285 . 十七巻 p. 133 , 平凡 社, 東京。

17）下中邦彦 編 (1962)：国民百科事典， 5 巻 p. 548,7 巻 p. 187 , 平凡社, 東京。

18) Slatter, D.H. ed. (1985) : Textbook of Small Animal Surgery, pp. 320-321, W.B. Saunders Co., Philadelphia.

19）相馬 智(1986)：基本的外科手術手技 - 標 準外科学 (武藤輝一, 相馬智 編) pp. 2345 , 医学書院, 東京。
20）高橋 貢 訳(1970)：小動物外科手術学の 基礎，pp. 70-71，医雪薬出版，東京。

21）高橋 貢，小笠原成郎 監訳 (1985)：大動 物の外科手術, pp. 80-81，文永堂，東京。

22）高橋信美，鈴木五郎 (1935)：実地外科手術 書，増訂 2 版，pp. 150-151，吐鳳堂，東 京。

23) Wingfield, W.E. and Kawlings, C.A. (1979) : Small Animal Surgery, An Atlas of Operative Techniques, pp. 3031, W.B. Saunders Co., Philadelphia. 